\title{
Official ACRL Documents
}

\section{Access}

Guidelines for the Preparation of Policies on Library Access. CERL News, December 1992. 10pp. \$2

\section{Audiovisual}

Guidelines for Audiovisual Services in Academic Libraries. CERL News, Oct. 1987. 4pp. $\$ 2$

\section{Bibliographic Instruction}

Guidelines for Bibliographic Instruction in Academic Libraries. CERI News, April 1977. 1p. \$2

Model Statement of Objectives for Academic Bibliographic Instruction. $C E R L$ News, May 1987. 6pp. \$2

\section{Colleges \& Universities}

Guidelines for Branch Libraries in Colleges and Universities. CERL News, March 1991 4pp. \$2

Guidelines for Extended Campus Library Services. CERL Neus, April 1990, Jan. 1993. 3pp. $\$ 2$

The Mission of an Undergraduate Library: Model Statement. CERL News. Oct. 1987. 3pp. $\$ 2$

Standards for College Libraries. CERL News, Mar. 1986. 12p. One copy free; additional copies $\$ 2$ each

Standards for University Libraries. CERL News, Sept. 1989. ACRL/ARL. 13p. Single copy free; additional copies $\$ 2$ each

\section{Community 8 Junior Colleges}

Standards for Community, Junior and Technical College Learning Resources Programs. Draft. $A C R L /$ AECT. CERL News, May 1994. 14pp. Single copy free; additional copies $\$ 2$ each

\section{Personnel Issues \& Faculty Status}

Guidelines for Academic Status for College and University Libraries. CERL Neus, March 1990 2pp. \$2

Joint Statement on Faculty Status of College and University Librarians. ACRL AAUP/AAC. CERL News, Feb. 1974. 1p. $\$ 2$

Model Statement for the Screening and Appointment of Academic Librarians Using a Search Committee. CERL News, Nov. 1992. 4pp. $\$ 2$

Model Statement of Criteria and Procedures for Appointment, Promotion in Academic Rank, and Tenure for College and University Librarians. CERL Neu's, May 1987. 8pp. \$2

Standards for Faculty Status for College and University Librarians. CERL Neus, May 1992. 2pp. \$2

Guideline on Collective Bargaining. CERL NeUS March 1993. 1p. $\$ 2$

Statement on the Terminal Professional Degree for Academic Librarians. 1975. 1p. $\$ 2$
Statement on the Certification \& Licensing of Academic Librarians. CERL News, Nov. 1989. 1p. \$2

\section{Rare Books, Manu- scripls, \& Archives}

Guidelines for Borrowing Special Collections Materials for Exhibition. CERL News, May 1990. 3pp. $\$ 2$

Guidelines for the Security of Rare Books, Manuscripts, and Other Special Collections. CERL News, March 1990. 5pp. $\$ 2$

Guidelines on the Selection of General Collection Materials for Transfer to Special Collections. CERL Neus, Dec. 1993. 4pp. \$2

Guidelines Regarding Thefts in Libraries. Draft. CERL News, May 1994. 6pp. $\$ 2$

Joint Statement on Access to Original Research Materials. CERL News, Dec. 1993. 2pp. $\$ 2$

Relator Terms for Rare Book, Manuscript, and Special Collections Libraries. CERL Neus, OCt. 1987. 5p. \$2

Standards for Ethical Conduct for Rare Book, Manuscript, and Special Collections Librarians with Guidelines for Institutional Practice in Support of the Standards. 2nd edition. CERL. News, April 1993. 9pp. \$2

Guidelines for the Loan of Rare and Unique Materials. CERL Neu's, May 1993. 3pp. $\$ 2$

Ilems on this page may be photocopied for noncommercial purposes, or order your copies from ACRL Official Documents, 50 E. Huron Si., Chicago, IL 60611. 